\title{
Commercial Mortgage-backed Securities: Prepayment and Default"
}

\author{
Brent Ambrose, Ph.D. \\ Professor of Finance and Kentucky Real Estate Professor \\ University of Kentucky \\ Anthony B. Sanders, Ph.D. \\ Professor of Finance and John W. Galbreath Chair in Real Estate Finance \\ The Ohio State University
}

February 19, 2002 


\title{
Commercial Mortgage-backed Securities: Prepayment and Default
}

\begin{abstract}
One of the major developments in real estate finance during the 1990s was the emergence of a viable market for commercial mortgage backed securities. The growth in this market has spurred greater interest in empirical and theoretical research on commercial mortgage default and prepayment. We employ a competing risks model to examine the default and prepayment behavior of commercial loans underlying CMBS deals. We find that changes in the yield curve have a direct impact on the probability of mortgage termination. Furthermore, we do not find any statistical relationship between LTV and prepayment or default.
\end{abstract}

Key Words: Commercial Mortgage-backed Securities; Competing Risks; Prepayment; Default 


\section{Introduction}

Default and prepayment on commercial loans have been examined in a number of papers (e.g., Vandell (1992), Vandell et al (1993), Kau et al (1990)). While many of these papers have been theoretical in nature, there is a growing literature on empirical estimates of prepayment and default. ${ }^{1}$ Typically, the data used in these studies comes from life insurance companies. In order to broaden the findings found in these studies beyond a single life insurance company database, we employ a database of commercial mortgages that underlie commercial mortgage-backed securities (CMBS) deals. The advantage of this database is that we have a larger number of loan originators and CMBS syndicators.

In this paper, we employ a competing risks model to examine the default and prepayment behavior of commercial loans underlying CMBS deals. We find that changes in the yield curve have a direct impact on the probability of mortgage termination. Furthermore, we find that mortgages with higher LTVs at origination are more likely to go the full term, but do not find any statistical relationship between LTV and prepayment or default. In terms of location, we find that mortgages on properties located in the west are more likely to prepay relative to the other three regions; furthermore, we also find that mortgages on southern properties are less likely to go to full term relative to those located in the west.

\section{Default on Commercial Mortgages}

The standard contingent claims approach to mortgage pricing infers that default is a function of loan attributes such as loan-to-value ratio (LTV) and debt-service coverage ratio (DCR). As the LTV increases on a loan, the contingent claims model approach results in an increase in default rates; similarly, as the DCR decreases, the contingent claims model approach 
results in an increase in default rates. In terms of prepayments, it is a function of loan attributes as well, including default. The exercise of the prepayment option leads to the termination of the default option (and vice-versa). These "competing risks" are quite important and complex in the commercial mortgage market, given the presence of prepayment lockouts, yield maintenance and defeasance. As interest rates decline, commercial mortgages are less likely to prepay if there are impediments such as prepayment lockouts; as a consequence, the default option increases in value as an alternative to prepayment. As credit quality declines, the chances of refinancing are lower (given the existence of prepayment lockouts and the resistance of lenders to recast loans that are in trouble). In addition to the aforementioned complexities, complex transactions costs related to default and prepayment (such as the complexities of the tasks of a special servicer) complicate the valuation process. Hence, problems exist with the contingent claims approach to mortgage pricing when applied to commercial mortgages.

\section{Adverse Selection and Competing Risks}

As Archer, Elmer, Harrison and Ling (2001) point out, another pitfall with applying contingent claim modeling to commercial mortgages is that variables such as LTV and DCR are endogenous to the loan origination process. Rather than simply present one contract to all applicants, lenders offer varying mortgage terms that control for the risk of default. For example, a lender considering high-risk loan applications can require higher down payments (lower LTVs). A lender perceiving a low level of default risk might be willing to accept a larger loan (higher LTV), all other things being equal. Alternatively, the lender can require a higher DCR for borrowers of lower quality and a lower DCR for borrowers of higher quality. In addition, the lender can alter mortgage terms in other ways to control for default risk such as 
reducing the term of the loan or asking for additional collateral. Hence, by trying to overcome the problem of adverse selection (high risk borrowers selecting high LTV terms), lenders screen applicants and sort them into groups and permit those groups to accept a fixed menu of terms.

If lenders control default risk by offering a menu of LTV and DCR, then it would be difficult to observe an empirical relationship between default and LTV or DCR. At the same time, lenders may charge a higher interest rate to higher risk borrowers and a lower rate to low risk borrowers. The high interest rates given to higher risk borrowers impact the likelihood of refinancing in that refinancing will be more difficult if the borrower is perceived to be of higher risk.

Following Archer, Elmer, Harrison and Ling (2001), we develop a model of commercial mortgage lending by assuming that the value of a loan, $\left(P_{L}\right)$, is the present value of its interest and principal repayments per face dollar of loan, less the expected value of losses from default per dollar of loan after adjustment for any guarantees or insurance and less the expected value of losses associated with prepayment, i.e.:

$$
P_{L}=V(\text { Pmts }, \text { Rpay }, y)-V\left(\text { LLoss }_{D}, \text { Ins }, y\right)-V\left(E \operatorname{Loss}_{P P}, y\right)
$$

where $y$ is the investor discount rate, Pmts are scheduled loan payments per dollar of loan, Rpay is any return of loan principal per dollar of loan, Eloss $_{D}$ is the vector of expected losses from default per dollar of loan, Ins is any mitigation of default loss from insurance or guarantees, and Eloss $_{P P}$ is the vector of expected losses from prepayment per dollar of loan. 
Expected default losses from a loan are contingent on the risk characteristics of the loan (e.g. LTV, DCR), risk characteristics of the underlying property (e.g. location) and other nonloan characteristics $(X)$ :

$$
\operatorname{ELoss}_{D}=L\left(L T V_{0}, D C R_{0}, X_{u}\right)
$$

where $L T V_{0}$ is the initial loan-to-value ratio, $D C R_{0}$ is the initial debt coverage ratio, and $X_{u}$ is a set of additional property and market characteristics observable at the time of loan origination. Expected prepayment losses are contingent upon risk characteristics associated with the embedded call option and reflect the expectation of future interest rates $(r *)$ as well as the presence of any prepayment penalties or lock-out provisions:

$$
\operatorname{ELoss}_{P P}=L\left(r_{*}, Z_{u}\right)
$$

where $Z_{u}$ is a vector of prepayment penalties or lockout provisions. The effective loan rate, $r_{l}$, is a function of the lenders required yield, $y$, on default-free, non-callable debt plus the expected loss rates, $\operatorname{LLosS}_{D}$ and ELoss $P$. Thus,

$$
\begin{aligned}
r_{1} & =R\left(\operatorname{ELoss}_{D}, \operatorname{ELoss}_{P P}, y\right) \\
& =R\left(L\left(L T V_{0}, D C R_{0}, X_{u}\right), L\left(r_{*}, Z_{u}\right), y\right)
\end{aligned}
$$

The likelihood of mortgage termination depends on the same determinants as initial expectation of expected losses: the required yield on default-free debt, the realization of stochastic events for 
the underlying property, $X_{P}$, the realization of future interest rates, and provisions in the loan contract controlling borrower actions. In addition, since prepayment and default are substitutes, the likelihood of default (prepay) depends upon the option to prepay (default). Thus, the probabilities of termination are

$$
\begin{gathered}
P D e f=P D e f\left(L T V_{0}, D C R_{0}, X_{u}, y, X_{P}, \text { PPPay }\right) \\
P P P a y=P P P a y\left(r_{*}, Z_{u}, y, X_{P}, P D e f\right)
\end{gathered}
$$

The vector $X_{P}$ reflects the stochastic risk characteristics associated with the put and call options embedded in the mortgage contract. Consistent with the lengthy literature associated with theoretical mortgage pricing models (e.g. Kau, et al [1992, 1993, 1994], Schwartz and Torous [1992], and many others), the vector $X_{P}$ also contains information on the underlying volatility associated with stochastic risk characteristics. Since the risk characteristics at underwriting are largely unobservable, proxies for $X_{u}$ must be used. To empirically parameterize the model, observable property and location characteristics can be used such as location, capitalization rate, net operating income, and property type. In addition, the spread of the mortgage rate over the default-free bond rate can be used. Substituting proxies for $X_{u}$ gives the following model:

$$
\begin{gathered}
\text { PDef }=P \operatorname{Pef}\left(\operatorname{LTV}_{0}, D_{C} R_{0}, x_{u}, \text { Spread }, X_{P}\right) \\
P P P a y=P P P a y\left(\bar{r}_{*}, Z_{u}, x_{u}, \text { Spread }, X_{P}\right)
\end{gathered}
$$

Of course, PDef and PPPay are the ex-ante probabilities of default and prepayment that may differ from ex-post measurement of default and prepayment. 
To illustrate this point, we separate the mortgage into two types of borrower: high quality (a) and low quality $(b)$ with one lender $(c)$. The lender can perfectly distinguish between borrower qualities such that $a$ is identified as the high quality borrower and $b$ is the low quality borrower. The high quality borrower will be permitted to borrow a greater amount of debt (or attain a higher loan-to-value ratio); the low quality borrower will be restricted to a lesser loan amount (or lower loan-to-value ratio). Thus, the values of the loans to the two borrowers are:

$$
\begin{aligned}
& P_{a}=V\left(P_{\text {Pmts }}, \text { Rpay, y }\right)-V\left(\operatorname{ELoss}_{D, a}, \operatorname{Ins}_{a}, y\right)-V\left(\operatorname{ELoss}_{P P, a}, y\right) \\
& P_{b}=V(\text { Pmts, Rpay, y })-V\left(\operatorname{ELoss}_{D, b}, \operatorname{Ins}_{b}, y\right)-V\left(\operatorname{ELoss}_{P P, b}, y\right)
\end{aligned}
$$

Clearly, the value of the loan to borrower $b$ would have a lower value given that the expected default loss to $b$ is greater, with the expected default loss for each borrower given as:

$$
\begin{gathered}
\operatorname{ELoss}_{a}=\operatorname{ELoss}_{D, a}+\operatorname{ELoss}_{P P, a}=L\left(L T V_{0, a}, D C R_{0, a}, X_{u, a}, r_{*}, Z_{u, a}\right) \\
\operatorname{ELoss}_{b}=\operatorname{ELoss}_{D, b}+\operatorname{ELoss}_{P P, b}=L\left(L T V_{0, b}, D C R_{0, b}, X_{u, b}, r_{*}, Z_{u, b}\right)
\end{gathered}
$$

Since the lender has identified borrower $a$ as the higher quality borrower, the LTV (as well as DCR and $X$ ) for borrower $a$ is set at a higher rate than the parameters for borrower $b$ so that:

$$
\operatorname{ELoss}_{a}=\operatorname{ELoss}_{b}
$$

subject to the constraints that: 


$$
L T V_{a}>L T V_{b}, D C R_{a}<D C R_{b}, S P R E A D_{a}<S P R E A D_{b}
$$

If the lender can distinguish between borrower qualities, then the LTV and DCR (and other variables) will be adjusted to set the expected losses of borrower $a$ and $b$ to be the same. Thus, we should find no relationship between ex-post default rates on commercial loans. While the lender has some flexibility in charging the lower quality borrower $a$ higher interest rate (rather than a lower loan-to-value ratio), Stiglitz and Weiss (1981) show that the probability of default increases as the default premium in the loan contract rate increases. Hence, lenders will often employ a combination of a lower LTV and a higher contract rate (as well as DCR). The result that lower quality borrowers receive lower loan-to-value ratios still holds. Archer, Elmer, Harrison, and Ling (2001) support this hypothesis by finding no statistically significant relationship between LTV and default.

\section{Data}

In order to examine commercial mortgage prepayments and defaults, we employ the CMBS database that is available from Intex. Intex is one of the leading providers in the U.S. of historical cash flow, prepayment and default data. Intex gathers information from monthly servicing company remittance reports. They, in turn, form databases for each CMBS deal so that clients such as investment banking firms have access to historical cash flows detailing when (and how) they terminate.

For commercial mortgages, the Intex database contains time series observations on the

prepayment, delinquency and default information on commercial mortgages that have been securitized and traded publicly. The database includes loan specific data such as loan-to-value 
ratio (LTV), debt service coverage ratio (DCR), original balance, current balance, gross coupon, net coupon, net operating income (original and updated), debt service, amortization period, payoff, age, amortization type, frequency of payments, property type, location of underlying property, yield maintenance provisions, lockout period, mortgage type, ARM provisions, originators, syndicators and loan status. ${ }^{2}$

The advantage of the CMBS database is that it contains loan information for a large number of CMBS deals and syndicators (such as DLJ, Deutsche Bank, GMAC and SASC) as well as originators (ContiFinancial, GMAC, Confederation Life). As a consequence, there is a broader representation of loans than typically found in commercial loan research using a single life insurance company for data. The disadvantage of the CMBS database is that the time series is relatively short (restricted to the 1990s and 2000) when compared to life insurance company data. In addition, the life insurance data may contain additional information not available to Intex such as annual updates on the capitalization rate.

The statistics for the sample are presented in Table 1. The sample covers 4,257 commercial loans from 33 CMBS deals. The average original balance on the commercial loans is $\$ 5,305,255$ while the average original LTV is $68 \%$. The average DCR is 1.55 . The data is taken from 33 CMBS deals (see Table 1a) and represented by numerous financial institutions such as Merrill Lynch, Nomura, Lehman Brothers, Wells Fargo and Confederation Life (see Table 1b). As can be seen in Table 2, the majority of the commercial loans are from the south (44\%) and the west (29\%). In terms of property type (see Table 3), multi-family is the most common $(42 \%)$ followed by retail properties $(25 \%)$, hotel properties $(9 \%)$, and office properties $(7 \%)$. 
The outcomes of the loan sample are presented in Table 4 . Of the sample, $4 \%$ of the loans experienced default. The prepayment rate on the loans in the sample is $8 \%$ while $0.5 \%$ of the loans matured. The majority of the loans (87\%) are currently performing.

\section{Competing Risk Model}

Since prepayment and default are substitutes, we jointly model the competing risks of default and prepayment. Competing risks models are now commonly used in empirical research of mortgage termination. For example, recent studies by Ambrose and Capone [2000], Ambrose and LaCour-Little [2001], Clapp, et al [2001], and Deng, Quigley, and Van Order [2000] have focused on mortgage prepayment and default in residential mortgages while Ciochetti, Gau, and Yao [2000] focus on commercial mortgages.

The Appendix presents a preliminary analysis of mortgage termination by examining the individual hazard rates of prepayment and default. Although the life-table method outlined in the Appendix suggests that the hazards of default and prepayment differ, this methodology does not account for the competing-risks nature of the interaction between prepayment and default. These factors can be accounted for, however, by using competing-risks models like those developed for employment transitions. We first recognize that during our observation period a borrower prepays the mortgage, defaults, or else remains current through the end of the timeperiod of study (censored). For a single spell, the model specifies the joint distribution of two variables: the spell duration, $t$, assumed to be a continuous variable, and the exit route, $r$, which is an integer variable taking values in the set $\{1,2,3\}$ representing the three possible outcomes.

Furthermore, we assume a latent duration, $T_{j}$, exists for each possible exit route, $j$, where $T_{j}$ 
$(j=1,2,3)$ is the time required for the spell to end via exit route $j$. Therefore, the observed duration, $t$, is the minimum of the $T_{j}$.

Conditional on a set of explanatory variables, $x_{j}$, that capture time-varying financial/economic characteristics as well as static characteristics describing the loan's location and underwriting criteria, and parameters, $\theta_{j}$, the probability density function $(p d f)$ and cumulative density function $(c d f)$ for $T_{j}$ are

$$
\begin{gathered}
f_{j}\left(T_{j} \mid x_{j} ; \theta_{j}\right)=h_{j}\left(T_{j} \mid x_{j} ; \theta_{j}\right) \exp \left(-I_{j}\left(r_{j} \mid x_{j} ; \theta_{j}\right)\right) \\
F_{j}\left(T_{j} \mid x_{j} ; \theta_{j}\right)=1-\exp \left(-I_{j}\left(r_{j} \mid x_{j} ; \theta_{j}\right)\right)
\end{gathered}
$$

where $I_{j}$ is the integrated hazard for outcome $j$ :

$$
I_{j}\left(T_{j} \mid x_{j} ; \theta\right)=\int_{0}^{T_{j}} h_{j}\left(s \mid x_{j} ; \theta_{j}\right) d s
$$

and $h_{j}$ is the hazard function.

The joint distribution of the duration and outcome is

$$
f(t, r \mid x ; \theta)=h_{r}\left(t \mid x_{r} ; \theta_{r}\right) \exp \left(-I_{0}(t \mid x ; \theta)\right)
$$

where $x=\left(x_{1}, x_{2}, x_{3}\right), \theta=\left(\theta_{1}, \theta_{2}, \theta_{3}\right)$ and $I_{0}=\Sigma I_{j}$ is the aggregated integrated hazard. Thus the conditional probability of an outcome is 


$$
\operatorname{Pr}(r \mid t, x ; \theta)=\frac{h_{r}\left(t \mid x_{r} ; \theta\right)}{\sum_{j=1}^{3} h_{j}(t \mid x ; \theta)} .
$$

\section{Empirical Model}

The theoretical model developed in Section 2 outlined the relationship between default/prepayment and property values and interest rates. Unfortunately, we are unable to observe actual property values and interest rates that trigger default or prepayment. As a result, the second best alternative is to attempt to measure the extent to which the embedded options to prepay or default are "in-the-money". In probabilistic terms, option-pricing models predict that the probability of option exercise increases as the options move deeper into the money. Since prepayment and default are substitutes, the extent that one option is 'in-the-money' has an impact on the probability of exercise for the other option.

We capture the dynamics of the prepayment option value as it relates to changes in interest rates with variables measuring the level of interest rates relative to the contract rate and rate volatility. To capture the relative position of the market interest rate with respect to the contract rate, we add the variable, $P P O P T I O N$, which is defined as

$$
\operatorname{PPOPTION}(t)=\frac{r_{c}(t)-r_{G}(t)}{r_{G}(t)},
$$

where $r_{c}$ is the current contract interest rate (the net coupon) at $t$ and $r_{G}$ is the current 10-year Treasury rate at $t$. Thus, PPOPTION represents the time-varying relative interest rate spread. Given that new mortgages are indexed to the 10-year Treasury, a relative increase in the current 
coupon spread indicates that prepayment is becoming more valuable. Thus, positive values of PPOPTION indicate that the prepayment option is "in-the-money", while negative values of PPOPTION indicate that the prepayment option is "out-of-the-money." As an indicator of market expectations concerning future interest rates, we also include a measure of the term structure (YLDCURVE), defined as the 10-year Treasury bond rate minus the 1-year Treasury bond rate. Figure 2 shows the changes in the yield curve over the sample period and clearly indicates an overall flattening of the yield curve during the latter 1990s. During the sample period, the mean value of the yield curve was 1.18 indicating that on average the 10 -year Treasury bond rate was 118 basis points greater than the 1-year Treasury bond rate.

Kau et al [1993] argue that interest rate volatility has a significant impact on prepayment option value with prepayment declining as volatility increases. Accordingly, we include interest rate volatility, GS10_VOL, defined as the standard deviation of the 10 -year Treasury rate measured over the previous 24 months. From Figure 3, we see that interest rate volatility varied significantly over the sample period.

In addition to general changes in interest rates, changes in default risk premium will also impact the attractiveness of commercial mortgage refinance. Thus, we capture changes in credit risk premiums by including the spread between AAA and Baa rated corporate bonds (SPREAD) and the volatility of the spread $\left(S P D_{-} V O L\right)$. The spread volatility is measured as the standard deviation of the spread over the previous 24 months. Figure 4 shows the variation in the credit spreads over the sample period. In general, we observe a tightening of credit spreads between 1991 and 1998, followed by an increase in spreads in reaction to the crises in the fixed income markets in the Fall of 1998. Over this period, the average credit spread was 77 basis points. 
The majority of empirical prepayment models emphasize the impact of interest rates. However, the theoretical mortgage models (Kau et al, 1992; 1994), by emphasizing the competing risks nature of default and prepayment, note that changes in property values have a primary impact on default and thus by extension, a secondary impact on prepayment. Option pricing models emphasize that declines in property values increase the probability of default (by increasing the probability of negative equity) and thus reduce the probability of prepayment (due to the substitutability of prepayment for default). As a result, the presence of negative equity is directly related to the probability of default. The dummy variable $N E G E Q$ is a time-varying variable that denotes the presence of negative equity Unfortunately, we do not have monthly observations of the underlying property values. Thus, to estimate whether the borrower has negative equity, we inflate the property value at origination by the monthly cumulative return on the NAREIT Index since loan origination to obtain a monthly estimate of property value. ${ }^{3}$ The equity position is then calculated by subtracting the estimated property value from the current loan balance for each month. Finally, we set $N E G E Q$ equal to one for those observations where equity is negative.

In an attempt to limit the impact of property value declines, lenders utilize loan-to-value ratios that are designed to limit default risk by requiring borrowers to meet collateral conditions. However, the impact of LTV on prepayment is secondary as borrowers with higher LTV ratios at origination may face greater refinancing costs due to the need to have appraisals. To test for this effect, we also include the initial LTV in the model ( $L T V)$. Commercial property capitalization rates reflect the underlying property value and vary over time to reflect general market sentiment as to the conditions in the economy. Presumably, during periods of economic uncertainty when market values are lower (cap rates are higher), lenders exhibit greater caution in underwriting. 
Thus, we would expect that mortgages on properties with low cap rates at origination will have a higher probability of termination. Therefore, we include the property cap rate at origination $(C A P)$.

Unlike residential mortgages, commercial mortgages often have provisions that prevent or reduce the financial incentive to prepay. Prepayment lockout provisions prohibit the borrower from prepaying the mortgage during the lockout period. Another common prepayment provision is a yield maintenance penalty that requires the borrower to make a payment to the lender to cover the lost interest income resulting from a prepayment. To test for the impact of these provisions, we include dummy variables ( $L O C K$ and $Y L D)$ that indicate whether the mortgage was originated with a lockout provision or yield maintenance penalty. Given that lockout provisions prohibit prepayment, we include the dummy variable LOCKEXP that indicates whether the lockout expired in the previous month. We anticipate that the probability of prepayment will increase dramatically for mortgages that have prepayment lockouts expiring when the prepayment option is "in-the-money". Finally, we also include dummy variables to control for the property location (regional level), property type (hotel, office, multifamily, or retail with other being the holdout), and mortgage age (TIME and TIME_SQ) to capture the impact of mortgage seasoning on the baseline hazard. We include the square of mortgage age to capture any non-linearities in mortgage seasoning.

\section{Empirical Results}

Table 5 reports the results of our empirical competing risks model. Turning first to the impact of economic conditions on mortgage performance, we see that changes in the yield curve (YLDCURVE) have a direct impact on the probability of mortgage termination. The parameter 
coefficients for YLDCURVE are negative and statistically significant indicating that an increase in the slope of the yield curve lowers the probability that the mortgage will terminate (default, prepay, or mature). To put this in perspective, we calculate the odd-ratio as $e^{\beta}-1$, which shows the impact of a one-point change in the yield curve on the probability of prepayment or default. Thus, assuming an average yield curve of 1.18 , we see that a one-point increase in the yield curve results in a 70 percent decrease in the odds of prepayment $\left(e^{-1.22}-1\right)$. However, the same one-point increase in the yield curve only reduces the odds of default by 39 percent.

We also see that higher volatility in interest rates (GS10_VOL) also results in a significantly lower probability of termination. While at first this seems counter to the theoretical prediction from option pricing models that higher volatility increases the value of an option, the negative coefficients imply that value of future termination has increased due to the increase in volatility and thus the probability of current termination actually declines.

We find that the parameter coefficients on the spread between current interest rates and the mortgage contract rate (PPOPTION) are positive and statistically significant indicating that the hazard of termination (default or prepayment) increases as current market rates decline relative to the contract rate (i.e. the spread increases).

Turning to the effect of changes in credit spread (SPREAD), we find a statistically significant and negative relationship between default and credit spreads. This suggests that as the gap between AAA bonds and Baa bonds increases, the probability of default declines. We also find that increases in the volatility of credit spreads have a significantly positive impact on the probability of prepayment and default.

Finally, we do not find any statistically significant relationship between negative equity and default. However, for loans with negative equity, the probability of prepayment is 
significantly lower. To put this in perspective, the odds ratio indicates that the probability of prepayment is 11 percent lower for loans that have negative equity.

Examining the impact of variables that control for mortgage underwriting, we find that mortgages with higher LTVs at origination are more likely to prepay. However, we do not find any statistical relationship between LTV and default. As mentioned previously in the paper, we were not necessarily expecting a statistical relationship between LTV and default if the lenders only permitted the highest quality borrowers to obtain high LTV loans. We also do not find any relationship between capitalization rates and the probability of mortgage termination.

Not surprisingly, we find that mortgages that have a prepayment lockout are less likely to prepay sine prepayment lockouts prevent prepayment. Yet, the expiration of the lockout (LOCKEXP) does not have a significant impact on prepayment. However, the expiration of the lockout does increase the probability of default.

We do find a significantly negative link between mortgage prepayment and yield maintenance penalties; this is evidence that yield maintenance penalties are effective in deterring early repayment. Finally, examining property location shows that mortgages on properties located in the mid-west are more likely to prepay relative to the western region. While we have no prior beliefs as to why this would be the case, it is interesting nonetheless that there are regional variations in commercial loan prepayment. Consistent with variations in the economic cycles over the sample period covered in the study, we also find significant differences in the probability of prepayment and default across property type.

\section{Conclusions}


This paper has presented a competing risks model of prepayment and default for commercial mortgages using a database of commercial mortgages that underlie commercial mortgage-backed securities (CMBS) deals. Thus, this study provides a first glimpse of the default and prepayment characteristics of securitized mortgages, which may be different from mortgages originated for portfolios of life insurance companies.

Our results confirm the theoretical predictions of option pricing models that default and prepayment are directly affected by changes in the economic environment, specifically expectation of future interest rates as proxied by changes in the yield curve. We also find that mortgages with higher LTVs at origination are more likely to prepay, but we do not find a statistical relationship between LTV and the hazard of default. Finally, in terms of location, the results show that mortgages on properties located in the mid-west and south are more likely to prepay relative to properties in the west. 


\section{References}

Abraham, J. and S. Theobald. 1997. "A Simple Prepayment Model of Commercial Mortgages." Journal of Housing Economics 6, 31-59.

Ambrose, Brent W. and Charles A. Capone, Jr., 2000. "The Hazard Rates of First and Second Default", The Journal of Real Estate Finance and Economics, 20:3 275-293.

Ambrose, B.W. and M. LaCour-Little. 2001. "Prepayment Risk in Adjustable Rate Mortgages Subject to Initial Year Discounts: Some New Evidence.” Real Estate Economics, 29:2 305-328.

Archer, W., P. Elmer, D. Harrison, D. Ling. 2001. "Determinants of Multifamily Mortgage Default." University of Florida working paper.

Boyer, L.G., J.R. Follain, J. Ondrich, and R. Piccirillo. 1997. "A Hazard Model of Prepayment and Claim Rates for FHA Insured Multi-family Mortgages", working paper.

Capone, C.A.., Jr. and L. Goldberg. 1998. "Motivating and Modeling Multi-family Mortgage Prepayment Rates." working paper.

Cheng, D., A. Cooper, and J. Huang. 1997. "Understanding Prepayments in CMBS Deals." in Fabozzi, et al., editors, The Handbook of Nonagency Mortgage-Backed Securities. Frank J. Fabozzi Associates.

Ciochetti, B. and K.A. Vandell. 1999. "The Performance of Commercial Mortgages." Real Estate Economics 27:1 27-62.

Ciochetti, B.A., B. Gao, and R. Yao. 2000. "The Termination of Lending Relationships through Prepayment and Default in Commercial Mortgage Markets: A Proportional Hazard Approach with Competing Risks. Working paper. University of North Carolina.

Clapp, J.M., G.M. Goldberg, J.P. Harding, and M. LaCour-Little. 2001. "Movers and Shuckers: Interdependent Prepayment Decisions.” Real Estate Economics 29 411-450.

Deng, Yongheng, John M. Quigley, and Robert Van Order. 2000. Mortgage Terminations, Heterogeneity and the Exercise of Mortgage Options. Econometrica 68 (2): 275-307.

Elmer, P.J. and A.E. Haidorfer. 1997. "Prepayments of Multi-Family Mortgage-Backed Securities." Journal of Fixed Income 6:4 50-63.

Follain, J.R., W. Huang, and J. Ondrich. 1999. "Stay, Pay or Walk Away: A Hazard Rate Analysis of FHA-Insured Multi-Family Mortgage Terminations." working paper.

Follain, J.R., J. Ondrich, and G. Sinha. 1997. "Ruthless Prepayment? Evidence from MultiFamily Mortgages." Journal of Urban Economics 41 78-101. 
Goldberg, L. and C.A. Capone, Jr., 1997. "Motivation and Testing of a Double-Trigger Hypothesis for Multi-Family Loan Defaults." working paper.

Gross, A. J. and V. A. Clark. 1975. Survival Distributions: Reliability Applications in the Biomedical Sciences, New York: John Wiley and Sons, Inc.

Gyourko, J. and D. Keim. 1992. "What Does the Stock Market Tell Us About Real Estate Returns?" Real Estate Economics (formerly Journal of the American Real Estate and Urban Economics Association) 20(3) 457-485.

Kau, James B., Donald C. Keenan, Walter J. Muller, III, and James F. Epperson. “A Generalized Valuation Model for Fixed-Rate Residential Mortgages." Journal of Money, Credit, and Banking 24 (1992), 279-299.

Kau, James B., Donald C. Keenan, Walter J. Muller, III, and James F. Epperson. “Option Theory and Floating-Rate Securities with a Comparison of Adjustable- and Fixed-Rate Mortgages." Journal of Business 66 (1993), 595-618.

Kau, J. B., D.C. Keenan, W.J. Muller, and J.F. Epperson. 1990. "Pricing Commercial Mortgages and Their Mortgage-Backed Securities." Journal of Real Estate Finance and Economics 3:4 333-356.

Kau, James B., Donald C. Keenan, Taewon Kim. "Default Probabilities for Mortgages." Journal of Urban Economics 35:3 (1994), 278-296.

Kelly, A. and V.C. Slawson. 1999. "Commercial Mortgage Prepayment Penalties and the Value of Delay." working paper.

McConnell, John J. and Manoj Singh. 1994. Rational Prepayments and the Valuation of Collateralized Mortgage Obligations. The Journal of Finance 49 (3): 891-921.

Riddiough, T.J., and H.R. Thompson. 1993. "Commercial Mortgage Default Pricing with Unobservable Borrower Default Costs." Real Estate Economics (formerly AREUEA Journal) 21 256-291.

Schwartz, Edwardo S. and Walter N. Torous. "Prepayment, Default, and the Valuation of Mortgage Pass-through Securities.” Journal of Business 65:2 (1992), 221-239.

Stiglitz, J.E., and A. Weiss. 1981. "Credit Rationing in Markets with Imperfect Information." American Economic Review 71:3 393-410.

Vandell, K.D. 1992. "Predicting Commercial Mortgage Foreclosure Experience." Real Estate Economics (formerly AREUEA Journal) 20:1 55-88. 
Vandell, K. W. Barnes, D. Hartzell, D. Kraft, and W. Wendt. 1993. "Commercial Mortgage Defaults: Proportional Hazards Estimations Using Individual Loan Histories." Real Estate Economics (formerly AREUEA Journal) 21:4 451-480. 


\section{Appendix: Hazard Rates}

In order to examine the prepayment and default behavior of commercial mortgages underlying CMBS deals, we begin by defining the time to either termination, $T$, as a random variable, which has a continuous probability distribution, $f(t)$, where $t$ is a realization of $T$. The cumulative probability is defined as

$$
F(t)=\int_{0}^{t} f(s) d s=\operatorname{Pr}(T \leq t)
$$

and the survival function is defined as

$$
S(t)=1-F(t)=\operatorname{Pr}(T>t)
$$

The survival function indicates the probability that the time to termination will be of length at least $t$. The probability $(l)$ that termination will occur in the next short interval of time, $\Delta t$, given that the borrower has not terminated prior to time $t$ is characterized as

$$
l(t, \Delta t)=\operatorname{Pr}(t \leq T \leq t+\Delta t \mid T \geq t)
$$

and the hazard rate function is defined as

$$
h(t)=\lim _{\Delta t \rightarrow 0^{+}} \frac{\operatorname{Pr}(t \leq T<t+\Delta t \mid T \geq t)}{\Delta t}=\frac{f(t)}{S(t)} .
$$


The hazard rate indicates the rate of termination at time $t$, given the mortgage remains current until $t$.

Figure 1 shows the hazard rates for default and prepayment, respectively. Since, the observation are measured at discrete intervals (months), we compute the survival curves and hazard rates using the life-table method. ${ }^{4}$ The life-table method estimates the conditional probability that the mortgage will either default or prepay during month $i$, given that the borrower was still making payments at the start of $i .^{5}$ Thus for month $i$, the probability of surviving to $i$ is

$$
\hat{S}\left(t_{i}\right)=\prod_{j=1}^{i-1}\left(1-q_{j}\right)
$$

where $q_{j}$ is the conditional probability of failure (default or prepayment). For the first interval, the survival probability is set to 1.0 . The hazard rate is estimated as

$$
h(t)=\frac{d_{i}}{\left(n_{i}-w_{i} / 2-.5\right)}
$$

where $d_{i}$ is the number of events (defaults or prepayments) during month $i, n_{i}$ is the number of mortgages at risk at the beginning of $i$, and $w_{i}$ is the number of mortgages censored during $i$.

Coinciding with the expiration of prepayment lockout periods and prepayment penalties, we see a significant jump in the probability of prepayment in the $120^{\text {th }}$ month from origination. 
Another slightly smaller jump in the prepayment hazard occurs in month 180 , which again reflects a natural prepayment lockout expiration date. Reflecting the much lower incidence of default in the dataset, we see that the hazard of default is significantly lower than the hazard of prepayment over the typical mortgage term. However during the first 60 months from origination, both the hazards of prepayment and default are relatively similar. 
Table 1. Descriptive Statistics for the 4,257 Loans Underlying 33 CMBS Deals

\begin{tabular}{|lrrrr|}
\hline Variable & Mean & Std Dev & Minimum & Maximum \\
\hline ORIG AMORT. & & & & \\
(months) & 313.94 & 45.84 & 60.00 & 480.00 \\
ORIG TERM (months) & 121.59 & 32.51 & 9.00 & 336.00 \\
ORIG LTV (\%) & 68.27 & 9.58 & 10.00 & 143.30 \\
ORIG BALANCE & $\$ 5,305,255$ & $\$ 10,056,035$ & $\$ 91,868$ & $\$ 239,000,000$ \\
GROSS COUPON (\%) & 8.76 & 0.85 & 6.15 & 12.00 \\
NET COUPON (\%) & 8.60 & 0.82 & 6.06 & 12.00 \\
DSCR & 1.55 & 0.70 & 0.09 & 15.30 \\
\hline
\end{tabular}

Source: Intex 
Table 1a. Source of Data by Deal Number.

\begin{tabular}{lr} 
Deal Number & Percent \\
\hline CSF95AW1 & 1.56 \\
CSF97C01 & 3.17 \\
DLJ95CF2 & 3.44 \\
GMAC96C1 & 2.78 \\
MLM95C03 & 2.84 \\
ASC95D01 & 1.22 \\
ASC95MD4 & 0.19 \\
ASC96D02 & 2.65 \\
ASC96D03 & 2.42 \\
CMAC97M1 & 0.21 \\
DLJ95CF2 & 3.51 \\
DLJ96CF & 2.50 \\
FHL1762 & 0.79 \\
FNM96MO1 & 2.16 \\
FULB97C1 & 6.05 \\
FULB97C2 & 7.66 \\
LBC296C2 & 2.27 \\
LBC95CO2 & 1.50 \\
MCF93CO1 & 0.24 \\
MCF94MC1 & 0.41 \\
MCF95MC1 & 1.30 \\
MCF97CM1 & 3.38 \\
MCF97CM2 & 3.87 \\
MLM95CO3 & 3.17 \\
MLM96CO1 & 3.38 \\
MLM96CO2 & 6.40 \\
MLM97CO1 & 4.64 \\
MLM97CO2 & 0.02 \\
MSC197W1 & 2.67 \\
MSC198W1 & 6.40 \\
NAS98DO6 & 6.74 \\
SASC96CF & 9.67 \\
SMSC94M1 & 0.79 \\
\hline TOTAL & 100.00 \\
\hline & \\
\hline
\end{tabular}


Table 1b. Source of Data by Financial Institution and Entity.

\begin{tabular}{lr} 
Source of Loans & Percentage \\
\hline Arbor & $0.02 \%$ \\
Bloomfield & $0.30 \%$ \\
CSFB & $3.17 \%$ \\
CapSource & $0.06 \%$ \\
Champion & $0.11 \%$ \\
Citicorp & $4.51 \%$ \\
Column & $6.74 \%$ \\
Confederation Life & $9.67 \%$ \\
Conti & $1.88 \%$ \\
DLJ conduit & $2.37 \%$ \\
Daiwa & $1.07 \%$ \\
First Maryland & $0.02 \%$ \\
First Union & $6.07 \%$ \\
First Union & $9.22 \%$ \\
GE Capital & $0.75 \%$ \\
GMAC & $0.39 \%$ \\
Hanover & $0.19 \%$ \\
Healthcare Capital Finance & $0.02 \%$ \\
Hotel Mortgage Resouce & $0.04 \%$ \\
ING & $0.51 \%$ \\
John Hancock & $0.73 \%$ \\
Lehman & $12.19 \%$ \\
Liberty & $0.15 \%$ \\
Love & $0.04 \%$ \\
Merrill Lynch & $9.63 \%$ \\
Morgan Stanley & $2.52 \%$ \\
NA & $2.33 \%$ \\
NBD & $0.02 \%$ \\
Nationsbank & $3.38 \%$ \\
Nomura & $0.58 \%$ \\
Nomura conduit & $11.81 \%$ \\
Remsen & $0.02 \%$ \\
Smith Barney & $0.66 \%$ \\
ValuExpress & $0.02 \%$ \\
Value Line & $0.66 \%$ \\
Wells Fargo & $5.82 \%$ \\
Wingate & $0.15 \%$ \\
Unknown Source & $2.16 \%$ \\
\hline TOTAL & \\
\hline & $100.00 \%$ \\
\hline
\end{tabular}


Table 2. Loans by Region

\begin{tabular}{|ccc|}
\hline Region & Frequency & Percent \\
\hline & & \\
Midwest & 565 & 13.63 \\
North & 635 & 15.32 \\
South & 1838 & 44.34 \\
West & 1219 & 28.64 \\
\hline Total & 4257 & 100.00 \\
\hline
\end{tabular}

Source: Intex 
Table 3. Loans by Property Type

\begin{tabular}{|lrr|}
\hline Type & Frequency & Percent \\
\hline & & \\
Hotel & 402 & 9.44 \\
Industrial & 225 & 5.29 \\
Multi-Family & 1,804 & 42.38 \\
Office & 318 & 7.47 \\
Retail & 1,082 & 25.42 \\
Other & 426 & 10.00 \\
\hline Total & 4,257 & 100.00 \\
\hline
\end{tabular}

Source: Intex

Table 4. Loans by Outcome

\begin{tabular}{|lrr|}
\hline Outcome & Frequency & Percent \\
\hline & & \\
Default & 176 & 4.13 \\
Prepaid & 343 & 8.06 \\
Matured & 19 & 0.45 \\
Performing & 3719 & 87.36 \\
\hline Total & 4,257 & 100.00 \\
\hline
\end{tabular}

Source: Intex 
Table 5. Competing Risks Model of Commercial Mortgage Termination Estimated via Multinomial Logit.

\begin{tabular}{|c|c|c|}
\hline Parameter & $\begin{array}{l}\text { Default } \\
\text { Model }\end{array}$ & $\begin{array}{c}\text { Prepayment } \\
\text { Model }\end{array}$ \\
\hline Intercept & $\begin{array}{l}-7.991^{\text {** }} \\
(86.63)\end{array}$ & $\begin{array}{l}-6.252^{\star \star *} \\
(172.70)\end{array}$ \\
\hline LTV & $\begin{array}{l}-0.001 \\
(0.03)\end{array}$ & $\begin{array}{l}0.004 \\
(0.88)\end{array}$ \\
\hline CAP_RATE & $\begin{array}{l}-0.025 \\
(0.72)\end{array}$ & $\begin{array}{l}-0.012 \\
(0.49)\end{array}$ \\
\hline YLDCURVE & $\begin{array}{l}-0.492^{* * *} \\
(12.03)\end{array}$ & $\begin{array}{l}-1.216^{* * *} \\
(153.45)\end{array}$ \\
\hline GS10_VOL & $\begin{array}{c}-2.404^{* * *} \\
(6.80)\end{array}$ & $\begin{array}{l}-4.196^{* * *} \\
(61.70)\end{array}$ \\
\hline SPREAD & $\begin{array}{c}-2.101^{* * *} \\
(7.06)\end{array}$ & $\begin{array}{l}-0.265 \\
(0.39)\end{array}$ \\
\hline$S P D \_V O L$ & $\begin{array}{l}23.321^{* * *} \\
(96.23)\end{array}$ & $\begin{array}{l}14.226^{* * *} \\
(149.13)\end{array}$ \\
\hline$N E G \_E Q$ & $\begin{array}{l}-0.297 \\
(1.35)\end{array}$ & $\begin{array}{l}-2.206^{* * *} \\
(18.72)\end{array}$ \\
\hline PPOPTION & $\begin{array}{l}2.457^{\star * \star *} \\
(31.50)\end{array}$ & $\begin{array}{l}1.405^{* * *} \\
(59.42)\end{array}$ \\
\hline LOCK & $\begin{array}{l}-0.262 \\
(1.92)\end{array}$ & $\begin{array}{l}-0.870^{\star \star * *} \\
(50.50)\end{array}$ \\
\hline YLD_MAIN & $\begin{array}{l}0.044 \\
(0.08)\end{array}$ & $\begin{array}{l}-0.194^{\star *} \\
(3.95)\end{array}$ \\
\hline LOCKEXP & $\begin{array}{l}1.522^{* * t} \\
(9.78)\end{array}$ & $\begin{array}{c}0.043 \\
(0.004)\end{array}$ \\
\hline NORTH & $\begin{array}{l}-0.303 \\
(1.42)\end{array}$ & $\begin{array}{l}-0.088 \\
(0.45)\end{array}$ \\
\hline SOUTH & $\begin{array}{l}0.139 \\
(0.62)\end{array}$ & $\begin{array}{l}-0.166 \\
(2.37)\end{array}$ \\
\hline MIDWEST & $\begin{array}{l}0.042 \\
(0.03)\end{array}$ & $\begin{array}{c}-0.387^{* \star * *} \\
(6.44)\end{array}$ \\
\hline TIME & $\begin{array}{l}0.010 \\
(1.29)\end{array}$ & $\begin{array}{l}0.029^{* * t} \\
(149.89)\end{array}$ \\
\hline TIME_SQ & $\begin{array}{c}-7.00 \mathrm{E}-05 \\
(1.97)\end{array}$ & $\begin{array}{c}-7.00 \mathrm{E}-05^{* * *} \\
(71.20)\end{array}$ \\
\hline HOTEL & $\begin{array}{l}0.528^{*} \\
(3.46)\end{array}$ & $\begin{array}{l}-1.579^{* * *} \\
(13.74)\end{array}$ \\
\hline MULTIFAMILY & $\begin{array}{c}-0.006 \\
(5.00 \mathrm{E}-04)\end{array}$ & $\begin{array}{l}0.199 \\
(2.33)\end{array}$ \\
\hline OFFICE & $\begin{array}{l}0.135 \\
(0.16)\end{array}$ & $\begin{array}{l}0.517^{* * *} \\
(12.03)\end{array}$ \\
\hline RETAIL & $\begin{array}{l}0.568^{* * *} \\
(5.76)\end{array}$ & $\begin{array}{r}-0.050 \\
(0.13) \\
\end{array}$ \\
\hline
\end{tabular}


Log-Likelihood Ratio

$(\beta=0)$

$1464.96^{* * *}$

${ }^{* * *}$ - significant at the $1 \%$ level, ${ }^{* *}$ - significant at the $5 \%$ level, ${ }^{*}$ - significant at the $10 \%$ level. 
Figure 1: Estimated Hazard Rates

(Kaplan-Meier Method)

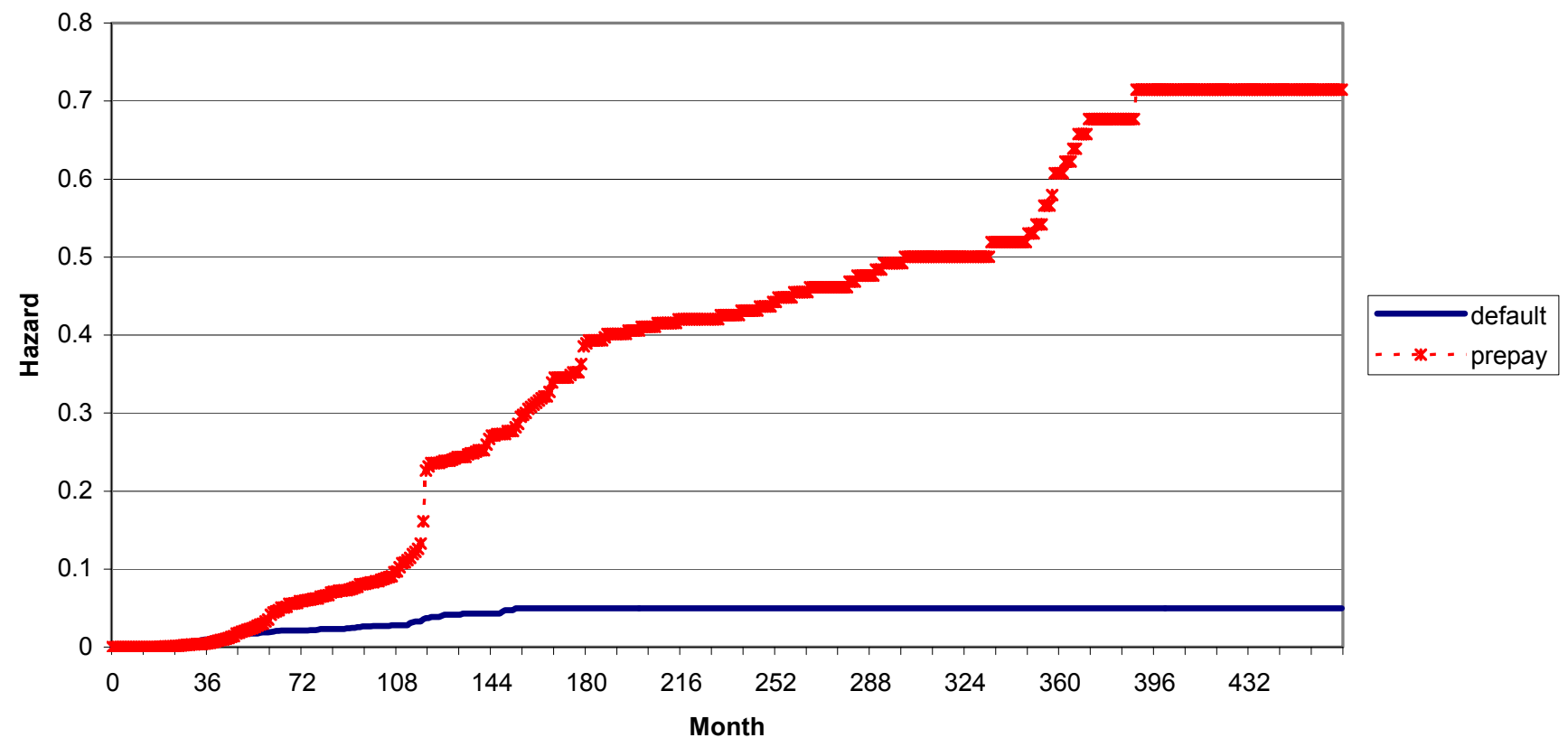


Figure 2: Yield Curve

(10 yr Treasury - 1 yr Treasury)

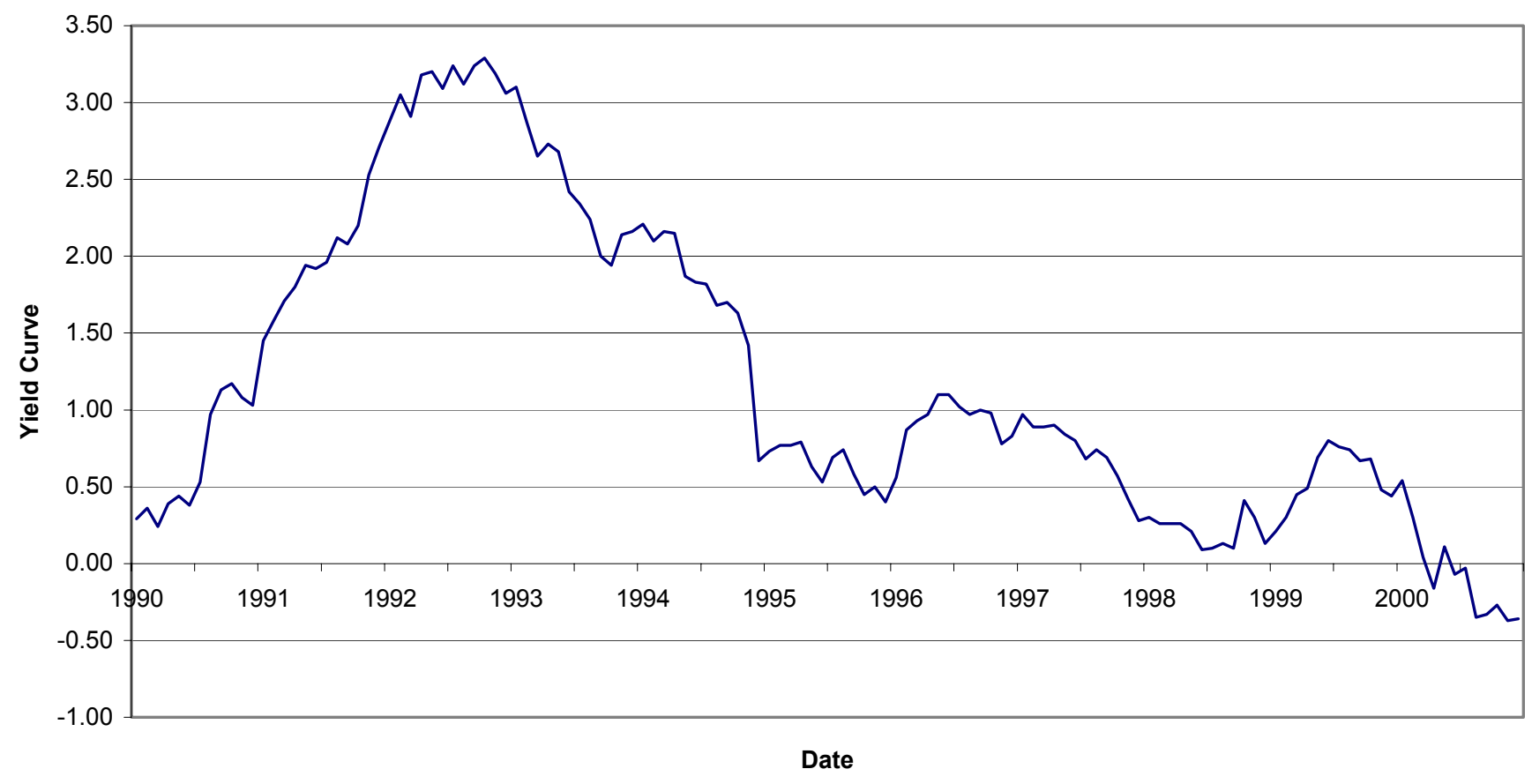


Figure 3: Interest Rate Volatility

(10-yr Treasury Bond Rate)

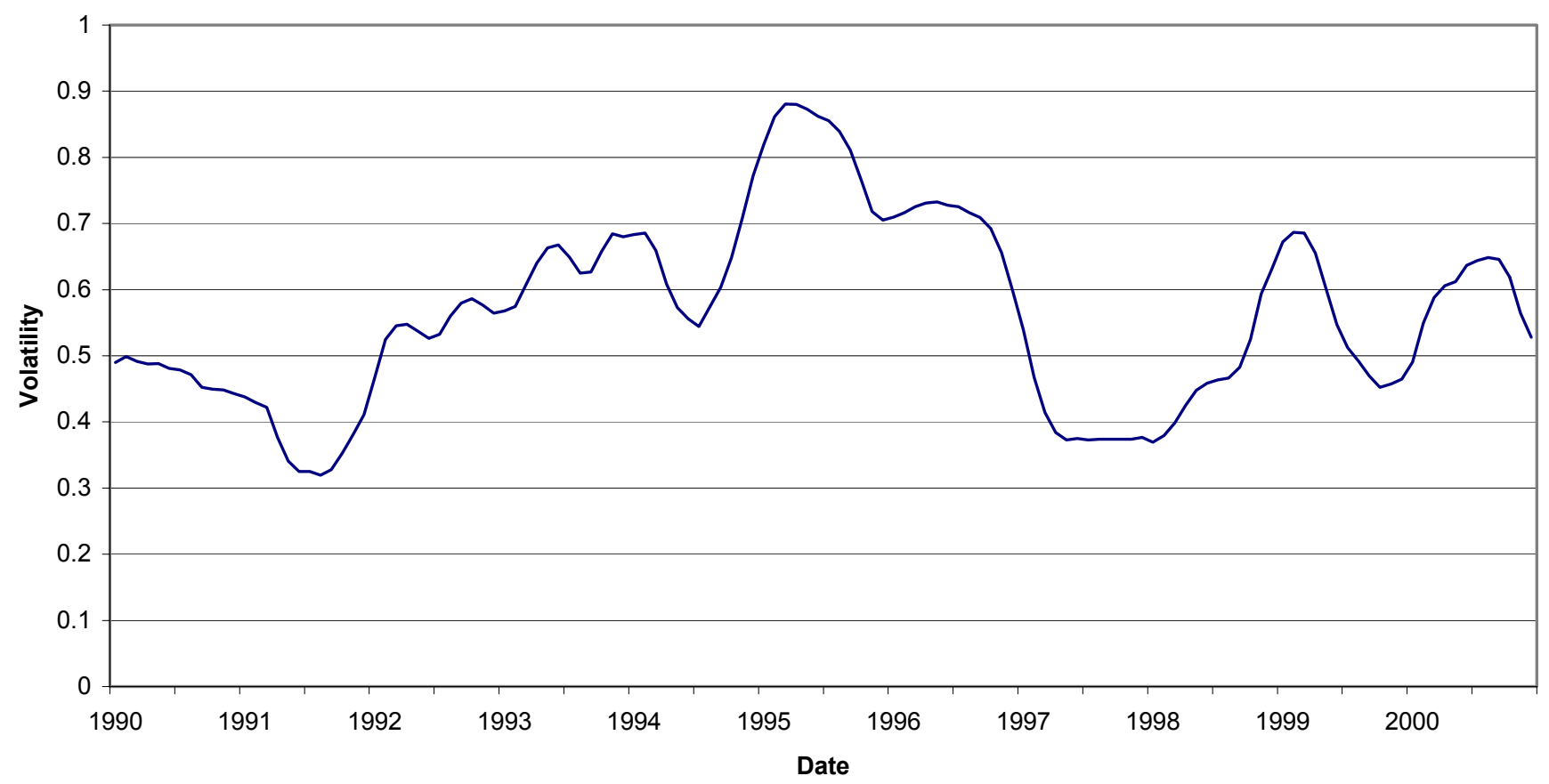


Figure 4: Credit Spreads

(AAA - Baa)

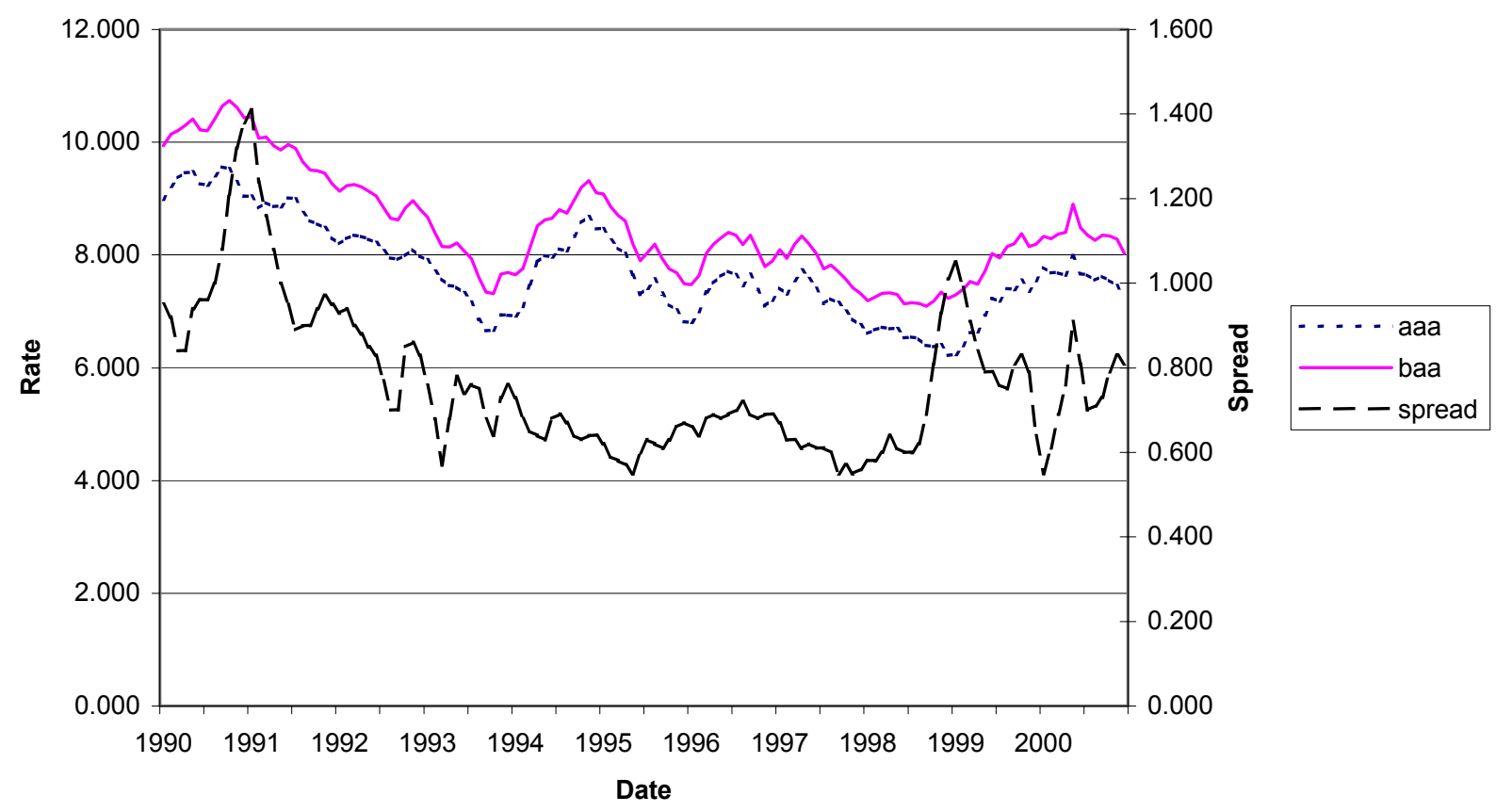




\section{Endnotes}

* The authors would like to thank Jean Helwege, Tyler Yang, and the participants at the 2001 Cambridge/Maastrict Conference for their helpful comments and suggestions as well as Intex for use of the CMBS database and RERI for financial support.

${ }^{1}$ For example, prepayments on commercial and multifamily loans have been analyzed by various studies including Abraham and Theobald (1997), Boyer, et al (1997), Capone and Goldberg (1998), Cheng et al (1997), Ciochetti and Vandell (1999), Elmer and Haidorfer (1997), Follain et al (1997), Kelly and Slawson (1999), McConnell and Singh (1994), and Schwartz and Torous (1992). Commercial mortgage default has been examined by studies including Archer, Ling and Harrison (1999), Boyer et al (1997), Ciochetti, et al (2000), Follain et al (1999), Goldberg and Capone (1997), Riddiough and Thompson (1993), Vandell (1992), and Vandell et al (1993).

${ }^{2}$ Unfortunately, the debt-coverage-ratio (DCR) is not consistently reported across all deals in the database. Thus, we are unable to include this variable in the statistical analysis.

${ }^{3}$ Although using the NAREIT Returns index is not without controversy, Gyourko and Keim (1992) provide evidence that the REIT returns do reflect fundamental movements in the real estate market.

${ }^{4}$ See Gross and Clark (1975) for a complete discussion of the life-table method of estimating survival functions.

${ }^{5}$ The conditional probability of default or prepayment is estimated as (number of loans that defaulted or prepaid in month $\mathrm{t}) /($ effective number of loans in the sample at month $\mathrm{t}$ ). 